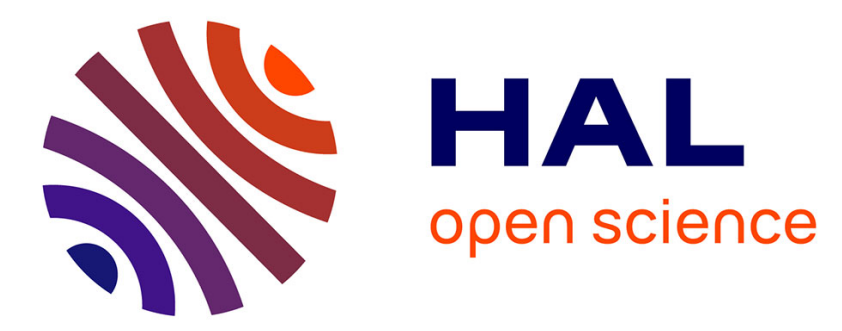

\title{
Srand specific PCR amplification of low copy number DNA
}

\author{
Andreas Meyerhans, Jean Pierre Vartanian, Simon Wain-Hobson
}

\section{To cite this version:}

Andreas Meyerhans, Jean Pierre Vartanian, Simon Wain-Hobson. Srand specific PCR amplification of low copy number DNA. Nucleic Acids Research, 1992, 20 (3), pp.521-523. 10.1093/nar/20.3.521. pasteur-03520147

\section{HAL Id: pasteur-03520147 \\ https://hal-pasteur.archives-ouvertes.fr/pasteur-03520147}

Submitted on 10 Jan 2022

HAL is a multi-disciplinary open access archive for the deposit and dissemination of scientific research documents, whether they are published or not. The documents may come from teaching and research institutions in France or abroad, or from public or private research centers.
L'archive ouverte pluridisciplinaire HAL, est destinée au dépôt et à la diffusion de documents scientifiques de niveau recherche, publiés ou non, émanant des établissements d'enseignement et de recherche français ou étrangers, des laboratoires publics ou privés. 


\section{Strand specific PCP amplification of low copy number} DNA

Andreas Meyerhans ${ }^{+}$, Jean-Pierre Vartanian and Simon Wain-Hobson ${ }^{*}$ Laboratoire de Rétrovirologie Moléculaire, Institut Pasteur, 28 Rue de Dr. Roux, 75724 Paris Cedex 15, France

Received October 3, 1991; Revised and Accepted January 7, 1992

\section{ABSTRACT}

A method for the amplification of a single DNA sirrand at low copy number is described. It is a wholly PCR based approach which involves an initial linear amplification of the target using a tagged sîrand specific primer. This is followed by classical PCR amplification of the progeny using a pair of primers, one specific for the sequence tagged onto the $5^{\prime}$ end of the first round primer, the second specific for the target sequence. Given the protocol used the ratio of the iwo sirano's in the final amplification product was 50:1.

\section{INTROOUCTUONO}

The replication of viruses frequently results in the unequal production of one of the two DNA or RNA strands. Replication of single stranded phage DNA by a rolling circle model being a case in point. Retroviral replication is also highly asymmetric involving RNA-dependent and DNA-dependent DNA polymerization by the viral reverse transcriptase and DNA-dependent RNA polymer-ization by the cellular RNA polymerase II. Recently we have described the phenomenon of $G \rightarrow A$ hypermutation of the human immunodeficiency genome whereby up to $40 \%$ of all $\mathrm{G}$ residues become substituted by $A(1)$. It is not known during which step of retroviral replication this phenomenon occurs.

In order to analyse better asymmetric viral replication processes we have developed a means of amplifying a low copy number single DNA strand in a two step PCR procedure involving both linear and exponential amplification cycles.

\section{MATERDARS AND METHODS}

Target sequences and amplification primers

The two single stranded M13 recombinant sequences used (L602R and L610) encoded 430bp complementary sequences derived from the second coding exon of the human immunodeficiecy virus type 1 (HIV-1) rev gene. These sequences map to $7880-8306$ on the HIV-1 Lai sequence $(2,3)$. They were identified as part of a longitudinal study of HIV-1 rev coding sequences in vivo (4). Within the region analysed in this study four mismatches were apparent between these complementary sequences (Fig. 1).

The sequences of the amplification primers were: SplA 5' CACCGCATGGATAGGATTGAGGACAGGCCCGACGGAAC; Sp1B 5' GGCAAGCTTCACCGCATGGATAGGATTGAG; and Sp2 5' CCCGAATTCCAGAAGTTCCACAAT$\mathrm{CC}$. The sequences specific for the HIV-1 rev sequences are shown underligned, while a randomly chosen sequence tagged onto the $5^{\prime}$ end of the SplA primer is shown in boldface. Restriction sites and clamps are shown in normal type. The second round primer Sp1B encoded only the random sequence along with a HindIII restriction site doubly (underligned) at the 5 ' extremity so as to facilitate cloning. Finally the HIV-1 specific $\mathrm{Sp} 2$ primer encoded an $E c o \mathrm{RI}$ site (doubly underligned) for the same reasons. All oligonucleotides were synthesized using phosphoramidate chemistry. After detritylation and alkaline deprotection, crude material was used for all applications without further purification.

\section{$\mathbb{P C R}$ amplification}

Approximately $3.10^{5}$ molecules of both single stranded recombinant M13 DNA (i.e. L602R and L610) were mixed together. Nine reactions were carried out involving three different SplA primer concentrations $(100 \mathrm{fmol}, 1 \mathrm{fmol}$ and $0.1 \mathrm{fmol})$ with respectively 10,50 and 100 linear amplification cycles. One fourth of the initial linear amplification reaction was taken and amplified for a further 35 cycles in an exponential amplification reaction using the $\mathrm{Sp} 2$ and $\mathrm{Sp} 1 \mathrm{~B}$ primer pair at a concentration of $100 \mathrm{pmol} /$ reaction. Amplification conditions were: $2.5 \mathrm{mM}$ $\mathrm{MgCl}_{2}, 50 \mathrm{mM} \mathrm{KCl}, 10 \mathrm{mM}$ Tris- $\mathrm{HCl} \mathrm{pH} 8.3,0.2 \mathrm{mM}$ dNTP, $2.5 \mathrm{U}$ Taq polymerase in a final volume of $100 \mu \mathrm{l}$ overlaid with $50 \mu$ l of heavy white mineral oil (Sigma). All amplifications were performed in a Perkin Elmer-Cetus thermal cycler. For linear amplifications the samples were first heated at $90^{\circ} \mathrm{C}$ for $5 \mathrm{~min}$. The denaturation, annealing and extension temperatures and times were $95^{\circ} \mathrm{C}(30 \mathrm{~s}), 50^{\circ} \mathrm{C}(1 \mathrm{~min})$ and $72^{\circ} \mathrm{C}(1 \mathrm{~min})$ respectively. For exponential amplification the parameters for denaturation,

* To whom correspondence should be addressed

+ Present address: Department of Virology, Institut for Medical Microbiology and Hygiene, University of Freiburg, D-7800 Freiburg, FRG 
annealing and extension were $95^{\circ} \mathrm{C}(30 \mathrm{~s}), 50^{\circ} \mathrm{C}(30 \mathrm{~s})$ and $72^{\circ} \mathrm{C}$ (30s) respectively followed by a final elongation step of $10 \mathrm{~min}$ at $72^{\circ} \mathrm{C}$. As a control the target sequences were amplified using the Sp2 and Sp1 A primers at 100pmol each for 35 cycles using the same conditions as described above. The final product size was $212 \mathrm{bp}$.

\section{Cloning and sequencing}

After amplification the reaction products were separated on a $0.8 \%$ low melting point agarose gel. The purified DNA was digested with EcoRI and HindIII and subsequently ligated into similarly cleaved M13mp18 RF DNA. The control DNA amplified by the Sp1A-Sp2 pair only was kinased and blunt end cloned into alkaline phosphatased treated $S \mathrm{maI}$ cleaved M13mp18 RF DNA. After transformation of $E$. coli strain TGl, recombinant M13 plaques were transferred to nitrocellulose filters and screened by hybridization with strand specific probes $\mathrm{P} 1$ and P2 which span the four base mismatches shown in Fig. 1. Their sequences are P1 5' AGACCTGCGGAGCCTGTT and P2 5'

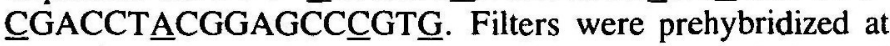
$50^{\circ} \mathrm{C}$ for $1 \mathrm{hr}$ in $4 \times \mathrm{SSC}, 0.5 \%$ SDS, $1 \times$ Denhardt's solution and $5 \mathrm{mg} / \mathrm{ml}$ denatured salmon sperm DNA. They were then transferred to a fresh solution (as above) containing $5^{\prime}{ }^{32} \mathrm{P}$ endlabeled and heat-denatured probe mix $\left(10^{6} \mathrm{cpm} / \mathrm{ml}\right.$ solution) and hybridized for 1 hour at $50^{\circ} \mathrm{C}$. Filters were washed three times with $0.1 \%$ SDS, $2 \times S S C$ at $50^{\circ} \mathrm{C}$. After autoradiography the ratio of $\mathrm{P} 1 / \mathrm{P} 2$ hybridizing plaques was established. To confirm the

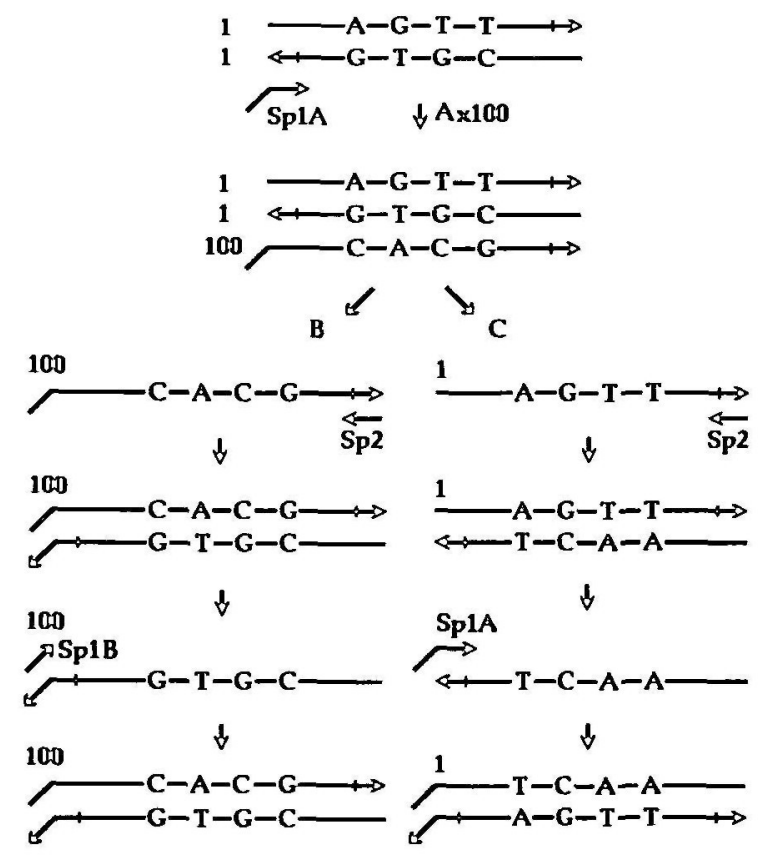

Figure 1. Schema representing strand specific amplification. The initial double stranded heterologous molecule is shown on top with the four mismatched base pairs. Using the SplA primer one of the two strands is amplified linearly $100 \times$ (A). Thereafter the Sp1B (specific for SplA) and Sp2 (specific for rev) primer pair are added and exponential amplification is now possible. During the first such cycle only Sp2 may serve as a primer. During the second SplB will prime polymerization from sequences tagged by the initial SplA primer (B). However there remains a little SplA primer, albeit at a non optimal concentration, which can now prime from the complementary copy to the undesired strand (C). Subsequent rounds results in the co-amplification of both strands. It is to be expected that the molar ratio of the two products will be of the order of 100:1 as shown. hybridization results $20 \mathrm{P} 1$ positive recombinant M13 clones were grown up and sequenced by the standard dideoxy method using $\left[\alpha-{ }^{35}\right]$ dATP $(600 \mathrm{Ci} / \mathrm{mmol})$ and resolved on buffer gradient gels.

\section{RESULTS}

The experimental plan is outlined in Figure 1. The four sites at which base mismatches occur between DNA strands are indicated. There are three distinct steps, A, B and C. Step A involved 100 cycles using the Sp1A primer of which the 17 most $3^{\prime}$ bases are complementary to the HIV-1 rev target sequence. This resulted in a linear amplification of one of the two strands yielding a relative ratio of approximately 100:1. Part of this reaction was taken and reamplified using the $\mathrm{Sp} 2 / \mathrm{Sp} 1 \mathrm{~B}$ primer pair resulting in a classical PCR reaction. During the first cycle of exponential, or classical PCR, the Sp2 primer copies both the plus strands preserving the ratio of 100:1. In the second cycle SplB, by virtue of its sequence identity to the $5^{\prime}$ most 21 bases of SplA will ensure amplification of sequences tagged by the SplA primer. It must be noted that there will still be some remaining Sp1A primer in the reaction (step C). During the second cycle of classical PCR the remaining Sp1A primer may anneal to the untagged complementary sequence and now copy this strand. In all subsequent cycles both strands will be amplified by the Sp2/Sp1B primer pair. However it is to be expected that the relative ratio of the strands will be $>100: 1$ since priming by SplB, being in molar excess over Sp1A, predominates. This assumes, of course, that the 100 single strand cycles are completely efficient.

A $25 \mu \mathrm{l}$ aliquot of products from the 10,50 and 100 linear amplifications was followed by 35 classical cycles of PCR. Two $10 \mu \mathrm{l}$ samples from each of the final reactions were electrophoresed on a $1.5 \%$ agarose gel and transferred to nitrocellulose. One filter was hybridized with the radiolabelled $\mathrm{P} 1$ probe, the other with $\mathrm{P} 2$. The autoradiograms are shown in Figure 2. The band intensities have been normalized to the control which contained an equimolar proportion of the two sequences as amplified by the Sp1A and Sp2 primer pair alone. As can be seen the signal intensities were much stronger using the $\mathrm{P} 2$ probe as opposed to the $\mathrm{P} 1$ probe. In order to quantitate precisely the proportion of the two strands the products from $3 \mathrm{~A}, 3 \mathrm{~B}$ and $3 \mathrm{C}$ (100 linear cycles) were cloned into the EcoRI and HindIII sites of M13mp18 RF DNA. The recombinant plaques were screened

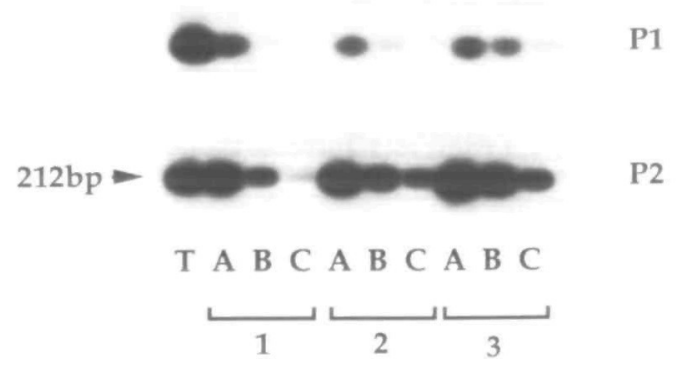

Figure 2. Analysis of strand specific DNA in the final PCR product. Probes P1 and $\mathbf{P 2}$ are specific for the desired and undesired DNA strands. Samples 1, 2 and 3 represent 10,50 and 100 linear amplification cycles while A, B and C refer to initial SplA primer concentrations of 100,1 and $0.1 \mathrm{fmol} /$ reaction respectively. The control lane $(\mathrm{T})$ represents a classical amplification of the target sequences using the $\mathrm{Sp} 1 \mathrm{~A} / \mathrm{Sp} 2$ primer pair. 
with $5^{\prime}$ labelled ${ }^{32} \mathrm{P}$ end-labelled $\mathrm{P} 2$ and $\mathrm{Pl}$ probes. The proportion of $\mathrm{P} 2: \mathrm{P} 1$ positive plaques was $60: 1,40: 1$ and 50:1 for samples $3 \mathrm{~A}, 3 \mathrm{~B}$ and $3 \mathrm{C}$ respectively indicating that background did not vary in proportion to the initial SplA primer concentration. From other work with these PCR amplified rev sequences we know that there is no preferential bias in the bluntend cloning of this fragment into M13.

To strengthen the results of the hybridization experiments 20 $\mathrm{P} 2$ positive recombinant $\mathrm{M} 13$ clones from reaction $3 \mathrm{C}$ were grown up and sequenced by the dideoxy chain terminator procedure. All 20 yielded the expected sequence shown in Fig. 1.

\section{DISCUSSION}

The protocol described allowed amplification of a specific DNA strand. The proportion of clones corresponding to the desired:undesired DNA strand was approximately 50:1 as identified upon direct screening of the cloned $3 \mathrm{~A}, 3 \mathrm{~B}$ and $3 \mathrm{C}$ products. That the complementary strand was detected may be attributed to the fact that during the second cycle of classical PCR the SplA primer, which still remained in the reaction, could anneal to the untagged strand. The ratio of the two products was less than the 100:1 ratio predicted were amplification to proceed with $100 \%$ efficiencies probably because the concentration of SplA primer was far from optimal, 100-0.1fmol as opposed to $100 \mathrm{pmol}$ in a normal PCR reaction. Presumably at such concentrations not all target molecules were saturated by primer within the 1 minute annealing time employed in the protocol. The concentration of primer was kept low so that any amplification between $\mathrm{Sp} 1 \mathrm{~A}$ and $\mathrm{Sp} 2$ in the round of PCR would be inefficient with respect to $\mathrm{Sp} 1 \mathrm{~B} / \mathrm{Sp} 2$ amplification. However the relative amplification factor of $\mathbf{5 0}$ is sufficient to allow the analysis of a number of biological processes.

An advantage of the method is that it is simple involving only two steps. As the sequence of the $\mathrm{Sp} 2$ primer was defined randomly it can be used to amplify any sequence so long as the corresponding sequence is included at the $5^{\prime}$ end of the initial linear amplification primer. Furthermore as there is little manipulation between the two amplification steps the risk of contamination is reduced.

Strand specific amplification of DNA has been exploited for a number of purposes. The most noticeable example being in the sequencing of single stranded DNA derived from a plasmid or phage (5). Other applications include strategies for chromosomal walking (6). The degree of amplification depends on the number of linear cycles of PCR. This works well when the imput DNA concentration is sufficiently high. A normal PCR amplification of a sequence from mammalian DNA employs $1 \mu \mathrm{g}$, or approximately 150,000 cell genome equivalents. The $3.10^{5}$ copies used in the protocol thus correspond to 1 copy/haploid DNA equivalent indicating that the procedure is capable of amplifying single mammalian gene sequences. Subsequent experiments with DNA dilutions showed that as little as 10 copies of single stranded M13 DNA could be detected (data not shown).

This simple method could be used for the amplification of one strand over another where the differences anticipated are of the order of $<50$. The study of DNA repair in vivo of artificially mismatched DNA sequences is an example. In these instances the use of viral vectors and plaque purification enabled analysis of progeny after transfection of cells by heteroduplex molecules. Restriction enzyme and sequence analysis showed that upon migration to the nucleus certain heteroduplexes were very efficiently repaired while others were much less so $(7-9)$. However these techniques rely on high copy numbers and a viral replicon and are therefore not readily applicable.

The method could be adapted to the analysis and quantitation of replication intermediates of RNA viruses if preceeded by an initial reverse transcriptase step. Finally it should prove useful in determining during which stage of the HIV-1 replication cycle $\mathrm{G} \rightarrow$ A hypermutation occurs (1).

\section{ACKNOWLEDGEMENTS}

This work was supported by grants from the Institut Pasteur and l'Agence National de Recherches sur le SIDA (ANRS). A.M. was a post-doctoral research fellow of the Centre International des Etudiants et Stagiaires and J.P.V. was supported by the Ministère de la Recherche et de la Technologie.

\section{REFERENCES}

1. Vartanian,J.P., Meyerhans,A., Asjö,B. and Wain-Hobson,S. (1991) J. Virol., 65, $1779-1788$.

2. Wain-Hobson,S., Sonigo,P., Danos,O., Cole,S. and Alizon,M. (1985) Cell, $40,9-17$.

3. Wain-Hobson,S., Vartanian,J.P., Henry,M., Chenciner, N., Cheynier,R., Delassus,S., Pedroza Martins,L., Sala,M., Nugeyere,M.T., Guétard,D., Klatzmann,D., Gluckman,J.C., Rozenbaum,W., Barré-Sinoussi,F. and Montagnier,L. (1991) Science 252, 961-965.

4. Pedroza Martins,L., Chenciner,N., Ásjö,B., Meyerhans,A. and WainHobson,S. (1991) J. Virol., 65, 4502-4507.

5. Gyllensten,U.B. and Erlich,H.A. (1988) Proc. Natl. Acad. Sci. USA, 85, $7652-7656$.

6. Rosenthal,A. and Jones,D.S.C. (1990) Nuc. Acids Res., 18, 3095-3096.

7. Brown, T.C. and Jiricny,J. (1987) Cell, 50, 945-950.

8. Brown,T.C., and Jiricny,J. (1988) Cell, 54, 705-711.

9. Wiebauer,K., and Jiricny,J. (1989) Nature, 339, 234-236. 